\title{
Skreening Potensi Antibakteri pada Beberapa Spesies Rumput Laut terhadap Bakteri Patogen pada Udang Windu
}

\author{
Munifatul Izzati \\ Laboratorium Struktur dan fungsi tumbuhan
}

\begin{abstract}
Antibacterial activity of several local seaweeds has been screened. Most of these seaweeds species show antibacterial properties against pathogenic bacteria from species of Vibrio and Pseudomonas. The activity of seaweeds extracts were determined by type of solvent used in extraction. Respond of each pathogenic bacteria were also different to each type of extract. Most seaweeds show stronger activity against Pseudomonas rather than Vibrio. Caulerpa and Padina were more active against Pseudomonas compared to Sargassum and Gelidium. Compared to other seaweeds, Sargassum and Gelidium were more active against Vibrio. It is predicted that Sargassum is the the most suitable to be used in polyculture with tiger shrimp (Peneaus monodon), as this is the most active against the most dangerous pathogenic bacteria, Vibrio harveyi. Beside that, the active component of Sargassum is solved in water, therefore will be easier to diffuse into shrimp pond.
\end{abstract}

Keywords: Seaweeds, antibacterial activity, pathogenic bacteria, polyculture.

\section{PENDAHULUAN:}

Kecenderungan menurunnya produksi udang windu di perairan tambak adalah merebaknya penyakit pada udang yang disebabkan oleh bakteri bakteri patogen. Penambahan antibiotik kedalam perairan tambak akan menimbulkan kekebalan. Disamping itu, kandungan antibiotic pada komoditas udang menyebabkan jatuhnya harga udang di pasaran internasional. Untuk itu, perlu dilakukan penelitian untuk mencari alternatif lain dalam mengatasi merebaknya penyakit udang windu. Salah satu cara adalah dengan menguji kemampuan rumput laut dalam menghasilkan senyawa antibakteri alami.

Penelitian ini bertujuan untuk menguji kemampuan rumput laut dalam menghasilkan senyawa antibakteri . Hasil pengujian ini dapat dikembangkan untuk mendapatkan jenis rumput laut yang tepat untuk digunakan sebagai model budidaya ganda dengan udang windu. Keberadaan rumput laut penghasil antibakteri ini diharapkan dapat menurunkan jumlah bakteri patogen, sehingga mampu menurunkan kemungkinan berkembangnya penyakit yang menyerang udang windu.

\section{BAHAN DAN METODE}

a.Penelitian pendahuluan:

Penelitian pendahuluan ini bertujuan untuk menguji aktivitas ekstrak rumput laut yang difokuskan pada genus Halimeda. Spesies ini dipilih, karena dari berbagai penelitian sebelumnya menunjukkan bahwa Halimeda mengandung senyawa halimedatrial yang aktif terhadap bakteri patogen Vibrio harveyi.

\section{a.1. Lokasi, Persiapan penelitian dan ekstraksi:}

Penelitian ini dilaksanakan di 3 laboratorium, yaitu: a) Laboratorium Pengembangan Wilayah Pantai (LPWP) Undip, Jepara; b) Laboratorium Hama dan Penyakit di Balai Budidaya Air Payau (BBAP), Jepara. Dan c) Laboratorium PAU, ILMu Hayati, ITB, Bandung. Rumput laut Halimieda yang diteliti diambil dari perairan sekitar pulau Panjang, Jepara. Lokasi ini dipilih karena dekat dengan laboratorium baik di Laboratorium Penembangan Wilayah Pantai, Universitas Diponegoro maupun di Balai Budidaya Air Payau (BBAP), Jepara. Pertimbangan lainnya adalah kondisi perairan laut yang relatif lebih bersih, sehingga Halimeda tumbuh melimpah. Sebelum diekstraksi, Halimeda terlebih dahulu di bersihkan dengan menggunakan air. Hal ini dilakukan dengan tujuan untuk membersihkan dari garam dan parasit yang menempel. Ekstsraksi dilakukan dengan 
menggunakan 2 macam pelarut yaitu eter dan air. Pelarut eter dipilih karena menurut Harborne (1991) senyawa terpenoid larut dalam eter, sedangkan pelarut air dilakukan untuk menguji kemungkinan keberadaan senyawa terpenoid bentuk glikosida yang larut dalam air. Sebelum diekstraksi Halimeda direndam dalam air selama 24 jam, kemudian dicuci dan dijemur hingga kering. Ekstraksi dilakukan menurut metode yang telah dikerjakan oleh Vidayati dan Sridhar (1991), yaitu 200 gram Halimeda dilarutkan dalam 2 liter pelarut. Ekstraksi dalam eter dilakukan dengan menggunakan ekstraktor soxhlet, sedangkan pelarutan dalam air dilakukan dengan pemanasan pada suhu $60^{\circ} \mathrm{C}$. Ekstrak Halimeda kemudian diuapkan sampai kerig pada suhu $55^{\circ} \mathrm{C}$ (Vidayati dan Sridhar, 1991).

b. Uji aktivitas ekstrak Halimeda terhadap Vibrio harveyi.

Penelitian ini dilaksanakan di Laboratorium Hama dan Penyakit BBAP, Jepara. Ekstraksi Halimeda kering dilarutkan kembali dalam methanol, selanjutnya larutan diuji aktivitasnya terhadap $V$ harveyi dengan menggunakan metode difusi standar. Tujuan dari pengujian ini adalah untuk mencari nilai MIC (Minimal Inhibitory Concentration) dari ekstrak Halimeda. Prosedur pengujian aktivitas ekstrak Halimeda terhadap Vibrio harveyi adalah sebagai berikut:

1. Pelarutan kembali ekstrak Halimeda dengan menggunakan metanol. Sebanyak satu gram ekstrak Halimeda dilarutkan dalam $1000 \mathrm{ml}$ metanol (1000 mg/l). Selanjutnya dilakukan pengenceran bertingkat hingga diperoleh larutan ekstrak dengan konsentrasi antara $1 \mathrm{mg} / \mathrm{l}$ hingga $1000 \mathrm{mg} / 1$.

2. Perendaman cakram uji dalam larutan ekstrak dengan konsentrasi bervariasi. Variasi konsentrasi adalah $0 \mathrm{mg} / \mathrm{l} ; 10$ $\mathrm{mg} / \mathrm{l} ; 100 \mathrm{mg} / \mathrm{l} ;$ dan $1000 \mathrm{mg} / \mathrm{l}$. Pertimbangan dalam menggunakan variasi konsentrasi tersebut adalah penelitian serupa dengan rumput laut Caulerpa sp yang telah dilakukan oleh BBAP menunjukkan bahwa nilai MIC nya adalah $1000 \mathrm{mg} / \mathrm{l}$.
3. Pengeringan kembali cakram yang telah direndam dalam berbagai konsentrasi ekstrak tersebut. Hal ini dilakukan untuk menghilangkan metanol dari cakram penguji. Bakteri pathogen Vibrio harveyi yang digunakan adalah kultur murni koleksi Laboratorium Mikrobiologi, BBAP Jepara. Prosedur pengujian aktivitas dikerjakan dengan metode difusi standar menurut Vidayati dan Sridhar (1991) dengan 5 ulangan pada setiap perlakuan. Pengamatan dilakukan terhadap diameter zona jernih yang timbul disekitar cakram uji.

c. Penyempurnaan metode ekstraksi Halimeda.

Penyempurnaan metode ekstraksi ini diperlukan apabila hasil pengujian tidak menunjukkan adanya aktivitas antibakteri. Selanjutnya, disempurnakan dengan metode ekstraksi bertingkat. Prosedur ini dimulai dengan ekstraksi rumput laut Halimeda sp dalam pelarut non polar, yaitu dengan menggunakan larutan normal heksan, diikuti dengan pelarut semi polar dengan menggunakan metilen klorid (MTC). Ekstraksi diakhiri dengan pelarut polar etanol. Ketiga jenis ekstrak yang dihasilkan selanjutnya diuapkan hingga tinggal ekstrak padat, kemudian diencarkan kembali dengan pelarut masing masing. Selanjutnya dibuat berbagai macam konsentrasi mulai dari $1 \mathrm{mg} / 1,10 \mathrm{mg} / \mathrm{l} ; 100 \mathrm{mg} / \mathrm{l}$ dan $1000 \mathrm{mg} / \mathrm{l}$. Kedalam pelarut tersebut dimasukkan cakram uji yang telah disterilkan dengan menggunakan oven. Setelah dikeringkan, cakram diujikan terhadap bakteri Vibrio harveyi, dengan menggunakan metode difusi standar. Vibrio ditanam pada media khusus untuk Vibrio harveyi pada cawan Petri. Cakram yang telah direndam dalam masing masing ekstrak kemudian dikeringkan. Sebanyak tiga buah cakram diletakkan pada media yang telah ditanami dengan Vibrio harveyi. Setiap perlakuan diulang sebanyak 4 kali. Setelah 24 jam, dilakukan pengukuran terhadap zona jernih yang ada disekitar cakram.

d. Eksplorasi Senyawa Aktif dari 5 spesies rumput laut

Tahap ini dilaksanakan dalam rangka mencari kemungkinan adanya senyawa antibakteri 
pada spesies rumput laut lainnya. Jenis jenis rumput laut yang diuji adalah Halimeda sp; Caulerpa racemosa; Padina sp; Sargassum sp dan Gelidium sp. Semua rumput laut tersebut tumbuh pada kedalaman $1-2 \mathrm{~m}$, di sekitar perairan pantai Jepara. Rumput laut yang diperoleh dibersihkan dari kotoran dan organisme dengan menggunakan air laut. Ekstraksi dilakukan dengan menggunakan 2 macam pelarut, yaitu air dan metanol. Pengujian ekstrak lima spesies rumut laut tersebut dilakukan terhadap 8 (delapan) jenis baktari patogen, menggunakan metode diffusi standar.

\section{e. Uji aktivitas ekstrak Sargassum dan Padina kering}

Karena dari hasil penelitian sebelumnya menunjukkan bahwa Sargassum dan Padina adalah jenis rumput laut yang mempunyai aktivitas antibakteri relatif lebih tinggi dibanding jenis lainnya, maka selanjutnya dilakukan pengujian terhadap ekstrak kering dari kedua jenis rumput laut tersebut. Sargassum dan Padina dibersihkan dan dijemur hingga kering. Sampel kering kemudian diekstraksi dengan menggunakan 2 macam pelarut, yaitu air dan metanol. Dengan demikian terdapat empat (4) macam pengujian sebagai berikut: a) ekstrak air dari Sargassum kering, b) ekstrak metanol dari Sargassum kering, c) ekstrak air dari Padina kering dan ekstrak methanol dari Padina kering.

Semua ekstrak tersebut diuji aktivitasnya terhadap 8 jenis bakteri patogen, yaitu Vibrio harveyi, Vibrio albensis, Vibrio anguila, Vibrio parahaemoliticus, Pseudomonas pavanaceae, Pseudomonas denitrificans, Pseudomonas syntata dan Pseudomonas tetrolens. Setelah diinkubasikan selama 24 jam, dilakukan pengamatan terhadap aktivitas masing masing ekstrak dengan mengukur diameter daerah jernih (zona hambatan) yang timbul disekitar cakram.

\section{HASIL DAN PEMBAHASAN}

a. Hasil penelitian pendahuluan:

a.1. Hasil uji aktivitas antibakteri ekstrak rumput laut Halimeda

Hasil pengujian aktivitas antibakteri menunjukkan bahwa ekstrak rumput laut Halimeda baik dengan pelarut kloroform maupun eter tidak mempunyai aktivitas antibakteri terhadap Vibrio harveyi. Vibrio harveyi tahan terhadap semua konsentrasi ekstrak, mulai dari $1 \mathrm{mg} / \mathrm{l}$ hingga 1000 mg/l. Pengujian ekstrak dengan pelarut air Halimeda juga menunjukkan tidak ada aktivitas antibakteri terhadap $V$. harveyi. V. harveyi tahan terhadap semua konsentrasi ekstrak air dari rumput laut Halimeda.

Dari hasil pengujian ini dapat disimpulkan bahwa baik ekstrak kloroform, eter maupun ekstrak air dari Halimeda tidak mengandung senyawa aktif yang mampu menghambat pertumbuhan bakteri Vibrio harveyi. Demikian juga dari hasil pengujian terhadap aktivitas ekstrak Halimeda dengan metode ekstraksi bertingkat.

Hasil pengujian menunjukkan bahwa tidak ada aktivitas antibakteri pada semua ekstrak rumput laut Halimeda sp. Vibrio harveyi tahan terhadap ekstrak Halimeda dalam pelarut normal heksan, metilen klorid dan etanol pada semua tingkat konsentrasi. Dengan demikian, dapat simpulkan bahwa ekstrak Halimeda dalam semua jenis pelarut tersebut tidak mengandung senyawa aktif yang dapat menghambat pertumbuhan Vibrio harveyi.

b. Hasil uji aktivitas antibakteri ekstrak beberapa rumput laut terhadap bakteri bakteri patogen

Hasil penelitian sebelumnya menunjukkan bahwa ekstrak Halimeda tidak mempunyai aktivitas terhadap bakteri Vibrio harveyi, oleh karena itu penelitian selanjutnya dikembangkan dengan menguji aktivitas ekstrak dari lima spesies rumput laut yang lain terhdap 8 spesies bekteri patogen. Spesies rumput laut yang diuji aktivitasnya adalah Halimeda macroloba, Caulerpa racemosa, Padina sp, Sargassum polycistum dan Gelidium sp. Pengujian dilakukan terhadap bakteri patogen Vibrio harveyi, Vibrio albensis, Vibrio anguila, Vibrio parahaemolyticus, Pseudomonas pavanaceae, Pseudomonas syntata, Pseudomonas denitrificans dan Pseudomonas trtrolens. Hasil pengujian terhadap beberapa spesies dari genus Vibrio tersebut dapat dilihat pada grafik 1 . 


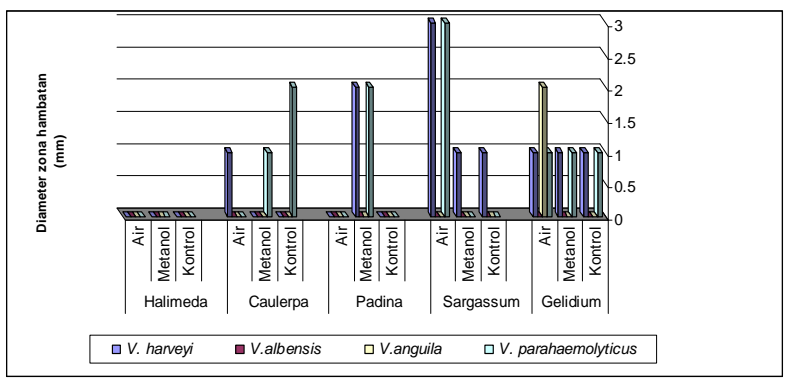

Grafik 1. Diameter zona hambatan hasil uji aktivitas ekstrak rumput laut terhadap beberapa spesies bakteri patogen kelompok Vibrio.

Secara umum, hasil pengujian menunjukkan bahwa Halimeda tidak mempunyai aktivitas menghambat terhadap pertumbuhan semua jenis bakteri Vibrio yang diuji. Ekstrak rumput laut Caulrepa sp mempunyai aktivitas menghambat terhadap pertumbuhan bakteri Vibrio harveyi, Vibrio anguila dan Vibrio parahaemolyticus. Zat aktif dalam Caulerpa sp terdapat pada ekstrak air maupun metanol.

Hasil pengamatan selanjutnya menunjukkan bahwa ekstrak Padina aktif terhadap bakteri Vibrio harveyi dan Vibrio parahaemolyticus. Zat aktif dari Sargassum terdapat baik pada ekstrak air maupun ekstrak metanol. Sedangkan ektrak rumput laut Gelidium sp mempunyai aktivitas menghambat Vibrio harveyi, Vibrio anguila dan Vibrio parahaemolyticus. Zaat aktif dalam Gelidium sp terdapat baik pada ekstrak air maupun metanol.

Dari hasil pengujian ini dapat disimpulkan bahwa rumput laut Sargassum $s p$ cocok/dapat dikembangkan untuk budidaya ganda dengan udang windu, karena ekstrak Sargassum aktif terhadap dua spesies bakteri Vibrio yang diuji. Disamping itu, aktivitas ekstrak Sargassum lebih tinggi dengan ditunjukkan zona hambatannya yang lebih luas dibanding dengan ekstrak rumput laut lainnya. Pengujian aktivitas rumput laut juga dilakukan terhadap beberapa jenis bakteri patogen dari genus Pseudomonas. Hasil pengujian ekstrak rumput laut terhadap beberapa spesies Pseudomonas dapat dilhat pada grafik 2 . Pseudomonas

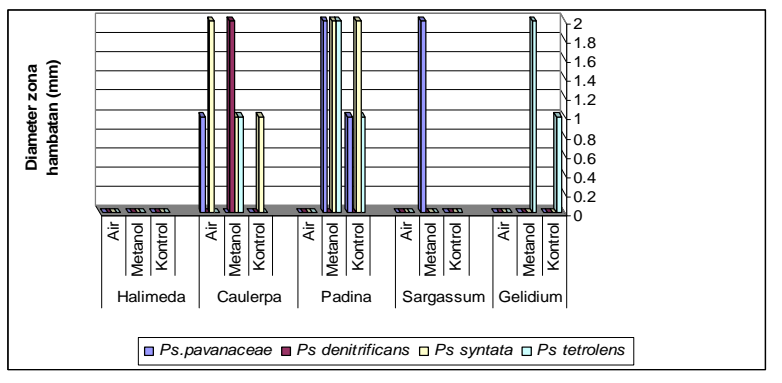

Grafik 2. Diameter zona hambatan hasil uji aktivitas ekstrak rumput laut terhadap beberapa spesies bakteri patogen kelompok Pseudomonas

Secara umum, hasil pengujian tersebut menunjukkan bahwa ekstrak Halimeda tidak mempunyai aktivitas terhadap semua bakteri yang diuji. Ekstrak air dari Caulerpa aktif terhadap Pseudomonas pavanaceae dan Pseudomonas syntata, sedangkan ekstrak metanol aktif terhadap Pseudomonas denitrificans dan Pseudomonas syntata, ekstrak air rumput laut Padina tidak dapat menghambat pertumbuhan semua spesies Pseudomonas yang diuji. Sementara itu, ekstrak methanol dari Padina aktif terhadap Pseudomonas pavanaceae, Pseudomonas syntata dan Pseudomonas tetrolens. Ekstrak air dari Sargassum tidak mempunyai aktivitas terhadap semua spesies Pseudomonas yang diuji,sedangkan ekstrak metanol aktif terhadap Pseudomonas pavanaceae sedangkan ekstrak metanol Gelidium aktif terhadap Pseudomonas tetrolens.

Dari hasil pengujian ekstrak rumput laut terhadap bakteri Pseudomonas dapat disimpulkan bahwa rumput laut yang cocok dikembangkan untuk budidaya ganda dengan udang windu adalah Padina sp. Kesimpulan ini diambil berdasarkan hasil pengujian yang menunjukkan aktivitas ekstrak Padina terhadap 3 jenis bakteri, yaitu Pseudomonas pavanaceae, Pseudomonas syntata dan Pseudomonas tetrolens. Caulerpa sp juga mempunyai aktivitas ekstrak terhadap 3 jenis bakteri Pseudomonas, akan tetapi kekuatan ekstrak Caulerpa diperkirakan lebih tinggi, karena daerah zona hambatan yang dihasilkan oleh Padina sp lebih luas disbanding dengan Caulerpa sp.

Secara keseluruhan, hasil penelitian ini menunjukkan bahwa jenis rumput laut yang efektif untuk menekan pertumbuhan bakteri Vibrio adalah Sargassum sp dan Padina sp yang efektif untuk 
menekan pertumbuhan bakteri Pseudomonas. Selanjutnya, jenis rumput laut yang akan diteliti untuk digunakan dalam budidaya ganda dengan udang windu adalah Sargassum. Alsan pemilihan Sargasum diantaranya karena senyawa aktif terdapat dalam ekstrak air sehingga lebih mudah terlarut dalam perarian tambak. Disamping itu, ekstrak Sargassum dapat menghambat pertumbuhan Vibrio harveyi. Bakteri ini merupakan penyebab penyakit kunang kunang, yang paling berbahaya bagi udang windu. Alasan lain, yang tidak kalah penting adalah melimpahnya Sargassum di perairan laut di seluruh Indonesia dan ukuran Sargassum yang lebih besar dibanding dengan Padina. Hal ini akan mempermudah dalam teknik budidaya di perairan tambak.

Sargassum memproduksi beberapa jenis senyawa sekunder, seperti florotanin (Keusgen dkk., 1997), steroid dan sterol (Faulkner, 1984). Menurut Hay dan Fenical (1988), florotanin mempunyai sifat antibakteri. Florotanin bersifat polar, sehingga larut dalam air dan bersifat tidak stabil (Glombitza Dan Keusgen, 1995). Berdasarkan pada hasil pengujian yang telah dilakukan, dapat diduga bahwa senyawa aktif dalam ekstrak air dari Sargasssum adalah florotanin.

c. Hasil uji aktivitas abibakteri dari ekstrak Sargassum dan Padina kering

Hasil pengujian aktivitas antibakteri pada ekstrak beberapa jenis rumput laut menunjukkan bahwa Sargassum dan Padina adalah jenis rumput laut yang dapat menghasilkan senyawa antibakteri. Senyawa aktif pada Sargassum larut dalam air, sedangkan pada Padina larut dalam pelarut metanol. Kedua jenis rumput laut ini dikembangkan sebagai sumber antibakteri. Akan tetapi, hasil penelitian menunjukkan bahwa ekstrak Sargassum dan Padina yang telah dikeringkan tidak menunjukkan adanya aktivitas antibakteri. Senyawa antibakteri yag terdapat pada Sargassum dan Padina bersifat tidak stabil. Hal ini sesuai dengan hasil beberapa penelitian tentang senyawa bioaktif dari rumput laut yang pada umumnya melakukan ekstraksi terhadap sampel segar (Ballantine et al., Paul dan Fenical, 1984, Rachmaniar, 1992). Paul dan Fenical (1984), menyatakan bahwa senyawa bioaktif pada
Halimeda, halimedatrial mengalami degradasi yang nyata, meskipun telah disimpan sebagai ekstrak kasar dalam pelarut metilen klorid. Dengan demikian dapat diduga bahwa senyawa bioakif yang terdapat pada Sargassum dan Padina juga mengalami perubahan setelah proses pengeringan, sehingga ekstsrak menjadi tidak aktif.

\section{KESIMPULAN}

Beberapa spesies rumput laut yang tumbuh di perairan pantai Jepara terbukti menghasilkan senyawa antibakteri yang aktif terhadap beberapa spesies bakteri patogen yang sering menyerang udang windu. Rumput laut Caulerpa sp, Padina $\mathrm{sp}$, Sargassum polycistum dan Gelidium sp menunjukkan adanya aktivitas antibakteri. Aktivitas antibakteri tersebut berbeda beda tergantung pada jenis pelarut yang digunaan untuk ekstsraksi. Respon bakteri patogen terhdap berbagai aktivits ekstrak dalam berbagai pelarut juga berbeda. Ekstrak rumput laut Halimeda sp dalam semua jenis pelarut tidak menunjukkan adanya aktivitas antibakteri baik terhadap bakteri Vibrio maupun Pseudomonas. Ekstrak rumput laut yang paling aktif terhadap bakteri Pseudomonas adalah Padina dan Caulerpa sp, sedangkan Sargassum polycistum dan Gelidium sp paling aktif menghambat pertumbuhan bakteri dari spesies Vibrio.

\section{DAFTAR PUSTAKA}

Ballantine, D.L., W.H. Gerwick dan S.M. Velez (1987): Antibiotic activity of lipid soluble extract from carribean marine algae. Hydrobiologia 151/152: 463 - 469.

Faulkner D.J. (1984). Marine natural products. Metabolites of marine alge and herbivorous marin mollusk. Nat. prod. Rep 1: 256-260

Glombitza K.W. dan M. Keusgen (1995): Fuhalols and dehydroxyfuhalols from the brown alga Sargassum spinoligerum. Phytochemistry Vol 38: No 4: 987-995.

Harborne J.B. (1987). metode kimia. penuntun cara modern menganalisis tumbuhan. Terbitan Kedua. Penerbit ITB, Bandung.

Hay, M.E. dan Fenical W. (1988. Marine plant herbivore interactions: the ecology of chemical defense. Ann. Rev. Ecol. Syst. 19: 111-145. 
Keusgen M., M Falk., J.A. Walyrt, K.W. Glombitza (1997): A Phloroglucinol derivative from brown alga, Sargassum spinuligerum. Journal of Chemical Ecology Vol 22: No 10: 34-39.

Paul V.J. dan Fenical W. (1984): Isolation of halimedatrial: chemical defense adaptation in calcareous reef building alga, Halimeda. Science 221: 747-748.
Vidayanti N dan Sridhar K.R. (1991): Seasonal and geographical variations in the microbial activity of seaweeds from mangrove coast of India. Botanica Marina 34:279-284. 